This article is licensed under the Creative Commons Attribution-NonCommercial 4.0 International License (CC BY-NC) (http://www.karger.com/Services/OpenAccessLicense). Usage and distribution for commercial purposes requires written permission.

\title{
Pediatric Tourette Syndrome: A Tic Disorder with a Tricky Presentation
}

\author{
Qurratul Warsi $^{a} \quad$ Caroline Kirby $^{\mathrm{b}} \quad$ Mirza Beg $^{\mathrm{b}}$ \\ ${ }^{a}$ University of California San Francisco, San Francisco, CA, USA; ${ }^{b}$ SUNY Upstate Medical \\ University, Syracuse, NY, USA
}

\section{Keywords}

Dysphagia · Eosinophilic esophagitis · Pediatric Tourette syndrome

\begin{abstract}
Dysphagia is a condition in which disruption of the swallowing process interferes with a patient's ability to eat. This may result in coughing or choking while swallowing, food sticking in the throat, or globus sensation. Eosinophilic esophagitis (EoE) is a chronic immune-mediated disease with a varied clinical spectrum of symptoms including dysphagia. Tourette syndrome (TS) is an inherited neurological disorder that manifests itself as a series of motor and vocal tics and may include oropharyngeal dysphagia. Dysphagia as a result of TS generally affects female, elderly patients and is not reported in children. While the pathophysiology is relatively unknown, experts believe TS is closely linked to damage or abnormalities in the basal ganglia of the brain. We present this interesting pediatric case of dysphagia due to EoE, which had been previously thought to be related to the patient's TS.




\section{Case Reports in Gastroenterology}

\begin{tabular}{l|l} 
Case Rep Gastroenterol 2017;11:89-94 \\
\hline DOI: 10.1159/000456609 & $\begin{array}{l}\text { ( ) 2017 The Author(s). Published by S. Karger AG, Basel } \\
\text { www.karger.com/crg }\end{array}$
\end{tabular}

Warsi et al.: Pediatric Tourette Syndrome: A Tic Disorder with a Tricky Presentation

\section{Introduction}

Tourette syndrome (TS) is an inherited neurological disorder that results in a series of motor and vocal tics [1]. The definitive diagnoses are based on the presence of multiple, involuntary motor tics and at least 1 vocal tic consistently occurring for 12 months [2]. Tics may be simple or complex hyperkinetic movements, often preceded by uncomfortable sensations localized at the site of the tics [3]. The pathophysiology of TS is unknown; however, it is known that a developmental disorder in the synaptic neurotransmission in the basal ganglia, particularly in the caudate nucleus, inferior prefrontal cortex, and frontal cortex, may play a role.

Eosinophilic esophagitis (EoE) is a chronic disease of the esophagus, mediated by an antigen-mediated immune response. It is more common in males with a mean age of presentation of 8.6 years. The age at diagnosis ranges from 5 months to 21 years. EoE presents with esophageal dysfunction, feeding problems, and food impaction leading to chest pain, choking, drooling and dysphagia. Histologically, eosinophil-predominant inflammation is evident [4]. The criteria for diagnosis include the presence of esophageal dysfunction, esophageal mucosal biopsy specimens containing more than 15 intraepithelial eosinophils per highpower field in 1 or more biopsy specimens, the absence of pathological gastroesophageal reflux disease as evidenced by a lack of response to high-dose proton pump inhibitor medication ( $2 \mathrm{mg} / \mathrm{kg} /$ day) or $\mathrm{pH}$ monitoring study of the distal esophagus [5]. Children frequently experience reflux symptoms, including heartburn and regurgitation, emesis, abdominal pain, dysphagia, and food impaction. The disease pathology is not well understood; however, there are multiple factors involving genetics, environmental exposures, and complex immune response. About $75 \%$ of the patients with EoE present with a concurrent atopic disease [6]. The sequel of atopy includes food allergies, environmental allergies, asthma, and atopic dermatitis. Typically, food allergies are to milk, eggs, corn, wheat, and soy [7]. Aeroallergen sensation is another cause, and patients with EoE frequently report seasonal variations, with fewer cases diagnosed during cold weather [8]. The genetics of EoE is under investigation. In some studies using murine models, the antigenic proteins may trigger the migration of eosinophils to gastrointestinal tissue. These antigens cause the adaptive T helper type 2 cell response that produces cytokines, such as interleukin-5 and interleukin- 13 . Interleukin-13 stimulates esophageal epithelial cells to produce a variety of proteins. The gene induced in this process is eotaxin-3, which recruits eosinophils from the peripheral blood into the esophageal tissue [9]. Further genetic analysis has also proven a single nucleotide polymorphism in the human eotaxin-3 gene [10].

\section{Case Report}

A 10-year-old Caucasian male with TS came to the emergency room with acute dysphagia and a food bolus impaction. On presentation, the patient was unable to swallow the saliva and was drooling excessively. This had happened to the patient in the past as well, but at that time the patient was able to cough and dislodge the impaction. The patient intermittently had choking episodes and had seen a neurologist for throat-clearing tics. On review of systems, the patient reported drooling, spitting, sore throat, difficulty swallowing, and chest 


\section{Case Reports in Gastroenterology}

Case Rep Gastroenterol 2017;11:89-94

(c) 2017 The Author(s). Published by S. Karger AG, Basel www.karger.com/crg

Warsi et al.: Pediatric Tourette Syndrome: A Tic Disorder with a Tricky Presentation

pain. He was diagnosed with TS at the age of 7 years. No known drug allergies were reported. The current medications included clonidine $0.1 \mathrm{mg} / \mathrm{ml}$ suspension and melatonin 3-mg tablets. The patient's immunizations are up-to-date. Physical examination revealed a blood pressure of $118 / 88 \mathrm{~mm} \mathrm{Hg}$, a pulse of $89 / \mathrm{min}$, temperature of $36.6^{\circ} \mathrm{C}$ (oral), and a respiratory rate of $19 / \mathrm{min}$. Respiratory, cardiovascular, and abdominal examinations were all within normal limits. HEENT (head, ears, eyes, nose, throat) examination revealed tenderness over the coracoid process and thyroid gland, but no palpable nodules or masses were noted. Petechiae were noted over the neck. The neck exhibited a normal range of motion and showed no rigidity. In the emergency room, the patient received $2 \mathrm{mg}$ of glucagon intramuscularly and fentanyl sodium $25 \mu \mathrm{g}$ pro re nata with no significant change in condition. Pediatric gastroenterology was consulted for an emergent esophagogastroduodenoscopy. The endoscopy revealed food impaction in the upper third of the esophagus, which was successfully removed (Fig. 1).

Mucosal changes were noted in the upper and lower esophagus. These changes included longitudinal furrows, edema, esophageal erosions, and mucosal friability (Fig. 2).

These findings were graded using the EoE endoscopic reference score (Table 1) [11]. Gastric and duodenal mucosae were normal. Mid and distal esophageal, gastric and duodenal biopsies were taken. Both esophageal biopsies revealed fragments of reactive squamous mucosa with increased intraepithelial eosinophils (more than 25 eosinophils per high-power field). The gastric biopsy revealed mild, focal chronic inflammation, and was negative for Helicobacter pylori. The duodenal biopsy was unremarkable. The patient was treated for EoE as per the NASPGHAN protocol with complete resolution of dysphagia symptoms. Twelve months into the therapy for EoE, the patient has no dysphagia.

\section{Discussion}

Dysphagia is a term used to describe difficulty swallowing. Dysphagia includes difficulty starting a swallow (oropharyngeal dysphagia) and the sensation of food being stuck in the neck or chest (esophageal dysphagia). Oropharyngeal dysphagia can result from abnormal functioning of the nerves and muscles of the mouth, pharynx, and upper esophageal sphincter. Esophageal dysphagia may result from narrowing in the esophagus caused by scarring due to acid reflux disease, inflammation of the lining of the esophagus, tumors within the esophagus, compression of the esophagus from growths in the chest or sometimes even an enlarged heart. It may also be caused by inflammation due to eosinophils, a condition known as EoE.

One of the symptoms resulting from a patient's TS is dysphagia. Coupled with a possible vocal and physical tic originating from the throat, difficulty swallowing is not unordinary. However, dysphagia as a result of TS generally affects female, elderly patients and is generally not seen in children. Our patient was presented with throat-clearing tics, choking episodes, and dysphagia, along with a history of TS. In our case, dysphagia was secondary to EoE as it improved after the EoE therapy. For our patient, the need to be seen by a pediatric gastroenterologist had been underemphasized. 


\section{Conclusion}

To our knowledge, this is the first reported case of EoE-induced dysphagia in a pediatric patient with TS. While rare, any case of TS presenting with a history of dysphagia must be investigated for EoE. Hence, we are reporting this case and giving future directions to primary care physicians and specialists to refer patients with TS and dysphagia to gastroenterology.

\section{Acknowledgement}

The authors would like to acknowledge Mr. Wahhaj Bakht, undergraduate at the University of Connecticut, Department of Ecology and Evolutionary Biology, for his help with editing the manuscript.

\section{Statement of Ethics}

The authors have no ethical conflicts to disclose.

\section{Disclosure Statement}

There is no conflict of interest regarding the publication of this paper.

\section{References}

1 Shprecher DR, Kious BM, Himle MH: Advances in mechanistic understanding and treatment approaches to Tourette syndrome. Discov Med 2015;20:295-301.

- Grados MA, Mathews CA: Clinical phenomenology and phenotype variability in Tourette syndrome. I Psychosom Res 2009;67:491-496.

- 3 Leckman JF, Walker DE, Cohen DJ: Premonitory urges in Tourette's syndrome. Am J Psychiatry 1993;150:98-102.

4 Liacouras CA, Furuta GT, Hirano I, et al: Eosinophilic esophagitis: updated consensus recommendations for children and adults. J Allergy Clin Immunol 2011;128:3-20.e6, quiz 21-22.

5 Furuta GT, Liacouras CA, Collins MH, et al: Eosinophilic esophagitis in children and adults: a systematic review and consensus recommendations for diagnosis and treatment. Gastroenterology 2007;133:1342-1363.

6 Orenstein SR, Shalaby TM, Di Lorenzo C, Putnam PE, Sigurdsson L, Mousa H, Kocoshis SA: The spectrum of pediatric eosinophilic esophagitis beyond infancy: a clinical series of 30 children. Am J Gastroenterol 2000;95:1422-1430.

-7 Spergel JM, Beausoleil JL, Mascarenhas M, Liacouras CA: The use of skin prick tests and patch tests to identify causative foods in eosinophilic esophagitis. J Allergy Clin Immunol 2002;109:363.

-8 Wang FY, Gupta SK, Fitzgerald JF: Is there a seasonal variation in the incidence or intensity of allergic eosinophilic esophagitis in newly diagnosed children? J Clin Gastroenterol 2007;41:451.

-9 Hogan SP, Mishra A, Brandt EB, Foster PS, Rothenberg ME: A critical role for eotaxin in experimental oral antigen-induced eosinophilic gastrointestinal allergy. Proc Natl Acad Sci USA 2000;97:6681.

-10 Blanchard C, Wang N, Stringer KF, Mishra A, Fulkerson PC, Abonia JP, Jameson SC, Kirby C, Konikoff MR, Collins MH, Cohen MB, Akers R, Hogan SP, Assa'ad AH, Putnam PE, Aronow BJ, Rothenberg ME: Eotaxin- 


\section{Case Reports in Gastroenterology}

\begin{tabular}{l|l}
\hline Case Rep Gastroenterol 2017;11:89-94 \\
\hline DOI: $10.1159 / 000456609$ & $\begin{array}{l}\text { ○ 2017 The Author(s). Published by S. Karger AG, Basel } \\
\text { www.karger.com/crg }\end{array}$ \\
\hline
\end{tabular}

Warsi et al.: Pediatric Tourette Syndrome: A Tic Disorder with a Tricky Presentation

3 and a uniquely conserved gene-expression profile in eosinophilic esophagitis. J Clin Invest 2006;116:536.

11 Dellon ES, Cotton CC, Gebhart JH, Higgins LL, Beitia R, Woosley JT, Shaheen NJ: Accuracy of the eosinophilic esophagitis endoscopic reference score in diagnosis and determining response to treatment. Clin Gastroenterol Hepatol 2016;14:31-39.

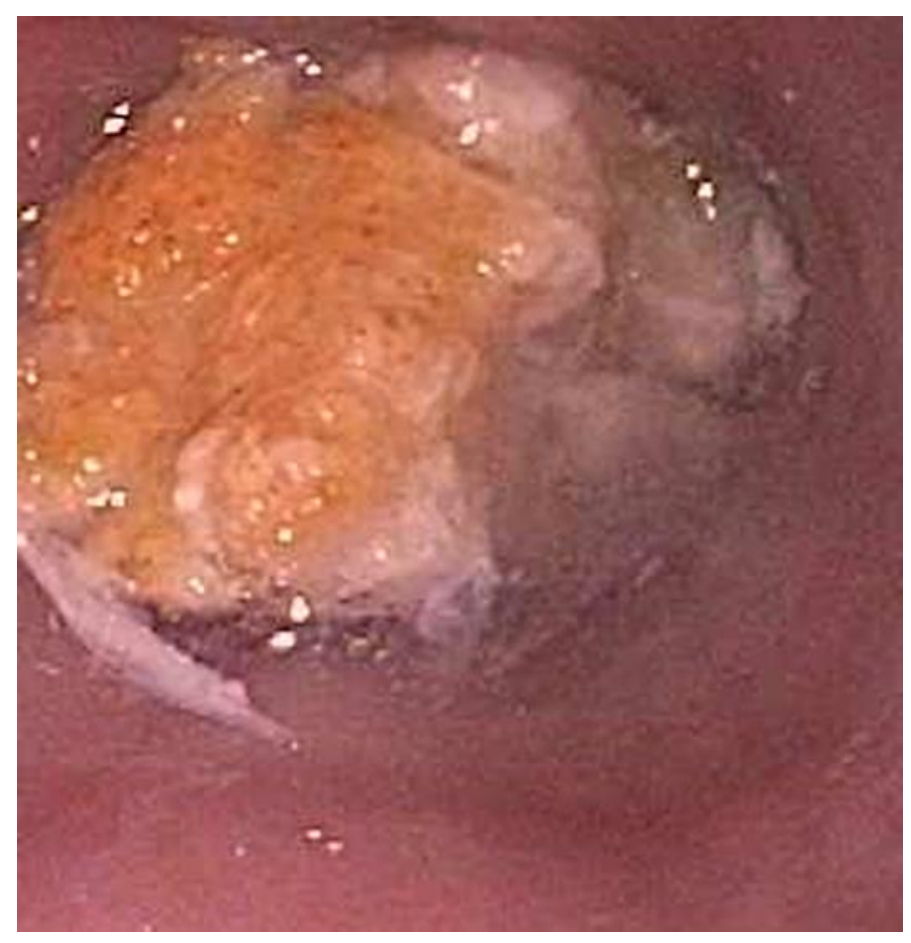

Fig. 1. Food impaction in the upper esophagus. 


\section{Case Reports in Gastroenterology}

Case Rep Gastroenterol 2017:11:89-94

DOI: $10.1159 / 000456609$

(C) 2

(C) 2017 The Author(s). Published by S. Karger AG, Basel www.karger.com/crg

Warsi et al.: Pediatric Tourette Syndrome: A Tic Disorder with a Tricky Presentation

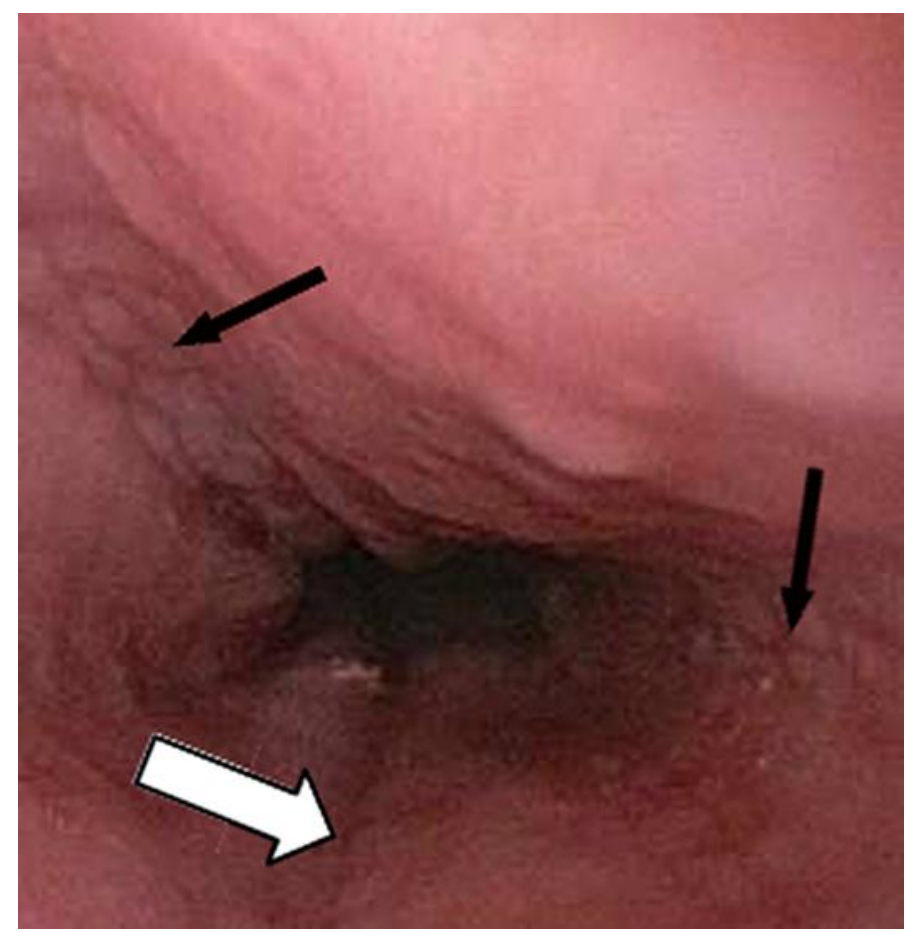

Fig. 2. Endoscopic appearance of eosinophilic esophagitis, illustrating linear furrows (white arrow) with mucosal pallor and loss of vascularity (black arrows).

Table 1. Eosinophilic esophagitis endoscopic reference score

\begin{tabular}{|c|c|c|c|c|}
\hline & Grade 0 & Grade 1 & Grade 2 & Grade 3 \\
\hline Edema (pallor) & Normal & Loss of vascular marking & - & - \\
\hline Ring (trachealization) & - & Mild & Moderate & Severe \\
\hline Exudate (plaque) & - & Mild & Severe & - \\
\hline Furrow (vertical lines) & Present/absent & - & - & - \\
\hline Stricture (luminal diameter) & Estimation of diameter & - & - & - \\
\hline
\end{tabular}

